\title{
Interactive teaching materials based on scientific approach: triangles and quadrilaterals
}

\author{
Heni Pujiastuti * \\ Mathematics Education Department, Universitas Sultan Ageng Tirtayasa, Jl. Raya Jakarta KM 4 \\ Serang, Indonesia
}

\begin{abstract}
One of the Indonesian government's efforts to improve the quality of education is by changing the curriculum. Currently the Curriculum 2013 is being implemented in schools. Implementation of Curriculum 2013 is require teaching materials in accordance with the characteristics of the students, utilizing computer technology facilities, and contains the components of the scientific approach. Therefore, it is necessary to develop teaching materials in accordance with the Curriculum 2013. In this research we developed the Interactive Teaching Materials based on Scientific Approach (ITMSA). The research method is research and development (R\&D) which consist of ten steps. The product design validation performed by multimedia, mathematics, and mathematics education expert involving lecturers and mathematics teacher. Utility testing of product conducted on junior high school students in Serang City, Banten Province, Indonesia. Based on research known that the ITMSA obtained a total score $85,30 \%$ from mathematics expert, $87,80 \%$ from mathematics education expert, $83,60 \%$ from multimedia expert, and $89,40 \%$ from students. In addition, students mathematical concept understanding who learn by using ITMSA better than student who learn without ITMSA. From these results concluded that the ITMSA is considered feasible and can be used in mathematics teaching in schools.
\end{abstract}

Keywords: Interactive teaching materials, Scientific approach, Triangles, Quadrilaterals

\section{Introduction}

Curriculum is a set of plans related to the content, ways, objectives and teaching materials used for guidance in conducting teaching and learning activities in order to achieve the goals of national education. The changing of curriculum by the Government of Indonesia is one form of efforts to improve the quality of education in Indonesia. Since 2013, the government began to enact the Curriculum 2013 which replaces the previous curriculum of the Curriculum 2006. Through the Curriculum 2013 is expected to build a generation of people who are able to compete globally in the future. The enactment of the Curriculum 2013 certainly gives a new nuance in the world of education, especially the nuances of learning held in the classroom by the teacher. The curriculum 2013 more

\footnotetext{
*Corresponding author: henipujiastuti@untirta.ac.id
} 
focuses on the use of scientific approaches and technology in classroom learning activities. Therefore, teachers are expected to create innovations that can bring new things, both in terms of methods, media, and learning resources are more adequate and meaningful.

However, the undeniable changes in the curriculum itself has many consequences, one of which is a lack of understanding of educators practitioners in implementing the new curriculum. In addition to training, To help the implementation of the Curriculum 2013 is needed the availability of learning resources such as the books or other teaching materials that can facilitate teachers and students to learn. To support the implementation of the Curriculum 2013, the government has published companion textbooks for teachers and students. The book contains the material presented based on a scientific approach that includes five steps: mengamati (observing), menanya (questioning), menalar (reasoning), mencoba (trying), and membuat jejaring (make a networking)[1].

Through scientific approach the expected learning becomes more meaningful for students and they become more active in the class. In the implementation, of course, required textbooks or other types of teaching materials that can guide teachers and students in learning, so that learning is more directed. However the presence of the companion text books that exist nowdays it is still not enough. In addition, government-published book is still in text book type, so it has not been able to facilitate students to learn through the use of technology. In the structure of Curriculum 2013, information and communication technology is no longer a subject taught, but as a learning tool contained in all subjects. This means that the skills of the use of information technology and communication facilities is absolutely necessary for students to make the learning process work well and learning objectives are achieved. Therefore, the aim of this study is to develop the Interactive Teaching Materials based on Scientific Approach (ITMSA). The developed of material in this research is the Triangle and Quadrilateral concept for seven grade of junior high school students.

\section{Methods}

This research used research and development method. In this method including 10 steps, namely: Preliminary Study, Planning Research, Development Design, Preliminary Field Test, Revised Results of Field Test, Main Field Test, Revised Result of Field Test, Feasibility Test, Revised Final Results of Feasibility, and Dissemination and Implementation Final Products[2].

- Preliminary Study: Perform needs analysis, literature studies, and small-scale research to determine the potential for product development and other information related to the planned product development.

- Planning Research: Formulate research objectives, estimate the budget, personnel and time, determine the qualifications of the researcher and the forms of participation in the research.

- Development Design: Determining the product design (hypothetical design), determine the research facilities and infrastructure needed during the research and development process, determine the stages of the implementation the trials design, and determine the description tasks of the parties involved in the research.

- Preliminary Field Test: Testing the product on a limited basis.

- Revised Results of Field Test: Revision of product design based on limited test.

- Main Field Test:

- Revised Result of Field Test: Testing the product on a wide scale.

- Feasibility Test: Conducting product experiments on large scale

- Revised Final Results of Feasibility: Refining the final product 
- Dissemination and Implementation Final Products: Publishing the results of the research through scientific forums. Product will distribution after the quality control stage.

The instruments used in the data collection include of validation sheet, student questionnaire, interview guidelines, and observation sheet.

\section{Results and Discussion}

The aim of the study is to develop the ITMSA. The development of the interactive teaching materials is conducted by researchers and assisted by four others as a team. The research team in this study is tasked to make the design of interactive teaching materials using a number of hardware and software required. The hardware used are Personal Computer with Intel Pentium 4 or AMD Athlon 64 processor specification, $2 \mathrm{~Gb}$ of RAM memory with 64 Bit VGA Video Card, and Android Smartphone version 2.2 Froyo. Some of the software used in developing this application is Adobe Flash Professional CS6, Adobe Illustrator Professional CS6, Notepad ++, and video needs software using ProShow Producer.

The material are developed in this interactive teaching material are the Triangle and Quadrilateral concept for seventh grade junior high school students. Until now, the ITMSA that are being developed are still in the design development stage. Figure 1 and Figure 2 are examples of the ITMSA view.
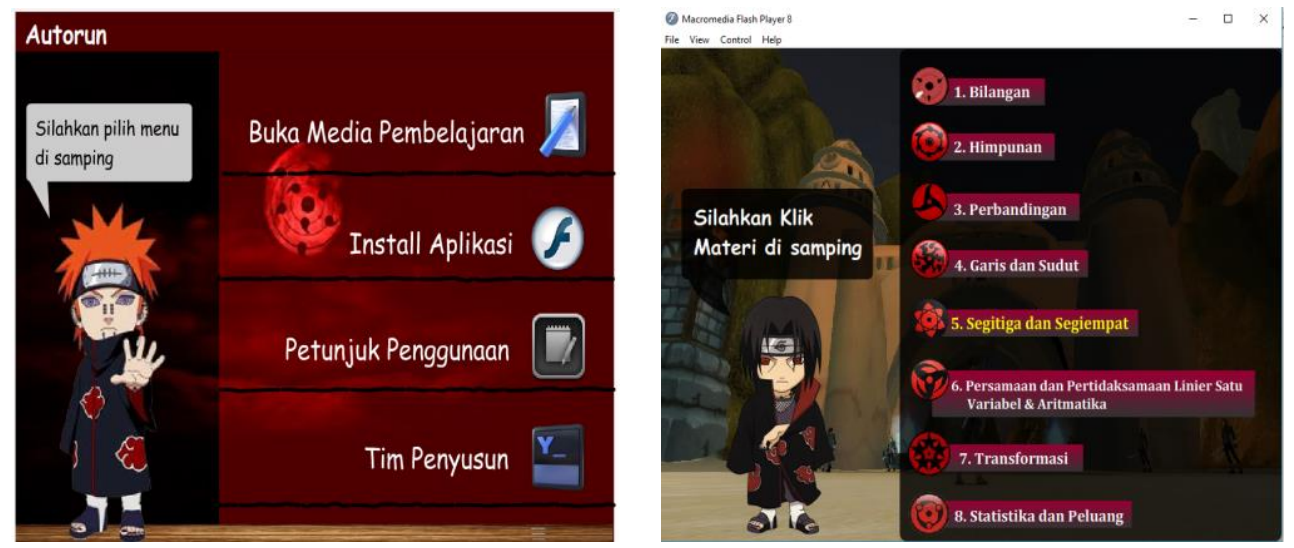

Fig. 1. The cover page view of ITMSA
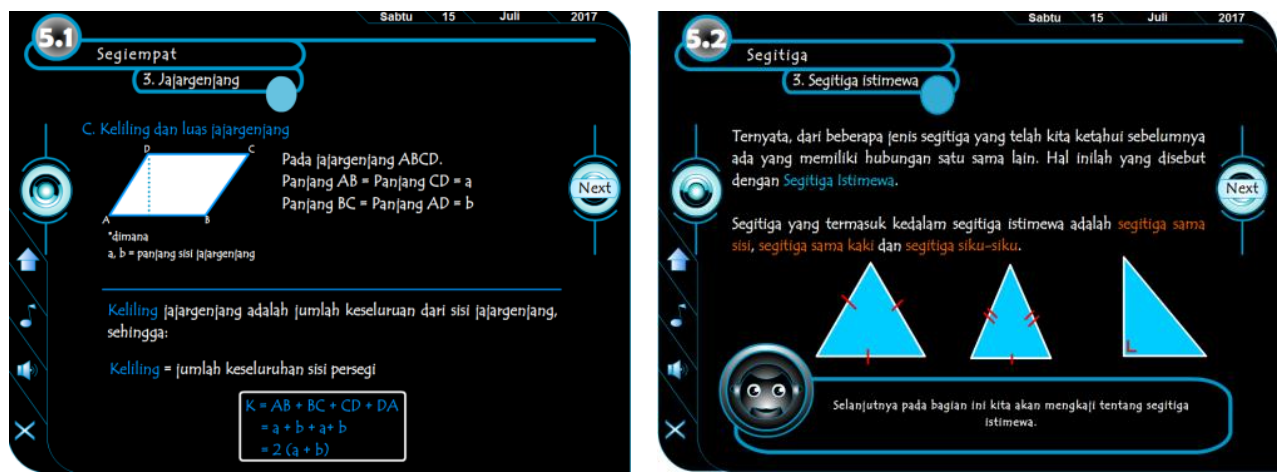

Fig. 2. The content view of ITMSA 
Interactive teaching materials that have been developed further validated by experts and tested in limited scale to a number of seventh grade junior high school students in Serang City. Based on the validation results, it is known that the ITMSA obtained a percentage of total score $85,30 \%$ from mathematics experts, $87,80 \%$ from educational experts, and $83,60 \%$ from multimedia experts. The results of limited trials to 30 junior high school students are obtained a percentage of total score $89,40 \%$. The results of validity test and limited test can be seen more clearly in Figure 3 below.

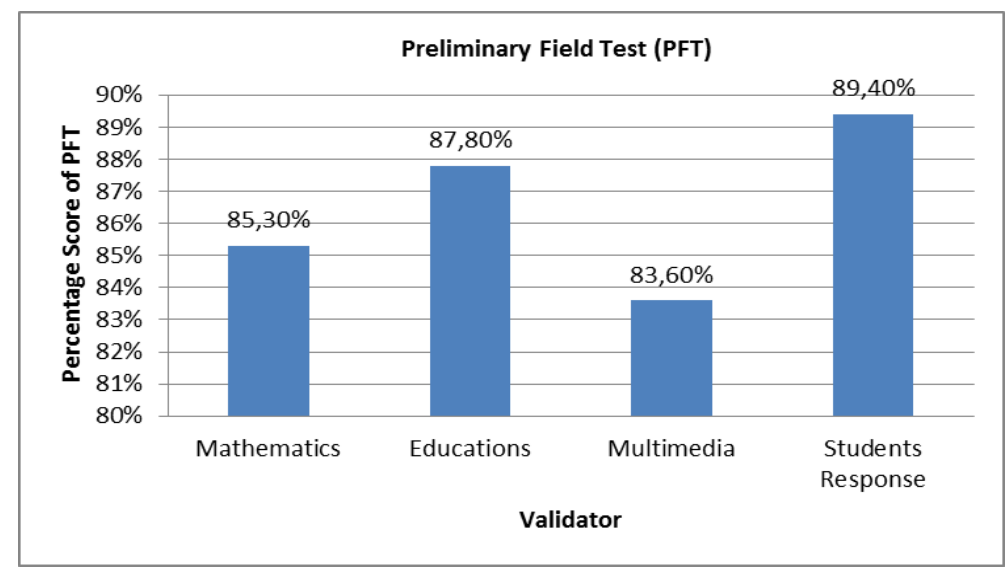

Fig. 3. Results of preliminary field test

After going through a process of expert validation and limited testing, subsequent trials were conducted on a wide scale to students in three different schools. Two classes were take from each schools, one class learning with the ITMSA and another class is learning without ITMSA. From the overall results of large-scale experiments, it is known that the scores of students mathematical understanding concept abilty who learn with ITMSA $85,38 \%$, while students who do not use ITMSA only $77,54 \%$. This is can be interpreted that the students mathematical understanding concept abilty who learn with ITMSA better than those who do not use the ITMSA. This result is in accordance with previous research that students mathematical understanding concept abilty in the Number concept who learn with ITMSA better than those who do not use ITMSA[3]. The recapitulation of large-scale test can be seen in the Figure 4 below.

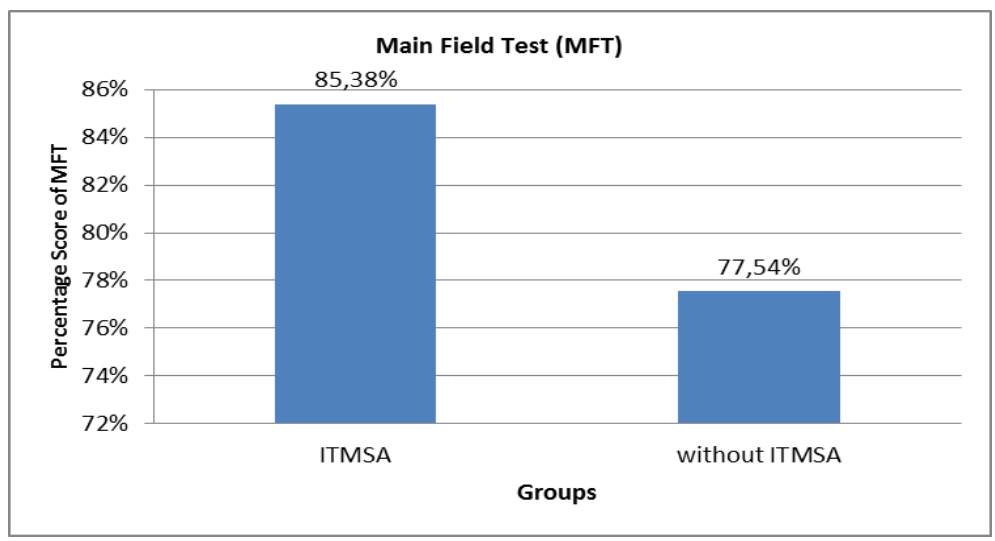

Fig. 4. Results of main field test 
From all of results test known that ITMSA obtained a percentage total score over than $70 \%$. It means that the ITMSA is considered feasible and can be used in teaching mathematics in school[4].

\section{Conclusions}

In this study it is known that the percentage of validation and test results is more than $70 \%$. In addition, the experimental results show that students mathematical understanding concept ability who learn with ITMSA is better than students who learn without ITMSA. These results indicate that ITMSA deserves to be a resource for students and teachers in the classroom. From all of results test it can be concluded that ITMSA is considered feasible and can be used in teaching mathematics in school.

The suggestions that can be given to further researchers are: 1) Developing interactive teaching materials for other mathematics concepts; 2) Testing interactive teaching materials in larger groups so as to know the effectiveness of teaching materials in improving students mathematics skills; 3) to be more focus on the high order mathematical thinking skill so that students mathematics skills are more improved.

We would like to thank to the Ministry of Research, Technology and Higher Education for the research grant (Penelitian Produk Terapan). Also similarly to the Institute of Research and Community Service, University of Sultan Ageng Tirtayasa who helped the process of research implementation.

\section{References}

1. Kemdikbud, Matematika SMP/MTS Kelas VII (Kementrian Pendidikan dan Kebudayaan, Jakarta, 2013)

2. W. R. Borg, M. D. Gall, Educational Research: An Introduction (Longman Inc, London, 1987).

3. H. Pujiastuti, Proceedings International Seminar on Mathematics, Science, and Computer Science Education (Faculty of Mathematics and Science Education, UPI, Bandung, 2015).

4. Puslitjaknov, Metode Penelitian Pengembangan (Pusat Penelitian Kebijakan dan Inovasi Pendidikan Badan Penelitian dan Pengembangan Departemen Pendidikan Nasional, Jakarta, 2008). 